\title{
IMPACT OF DEMONETIZATION ON INDIAN BANKING STOCKS: AN EVENT STUDY METHODOLOGY
}

\author{
Dr. Rajesh Raut \\ Assistant Professor \\ Modern Institute of Business Management, Pune, India \\ E-mail: dr.rwraut@gmail.com \\ Dr. Harsha Thorve \\ Associate Professor \\ Modern Institute of Business Management, Pune, India \\ E-mail: harsha.mibm@gmail.com \\ Dr. Shrawan Owhal \\ Professor \\ Modern Institute of Business Management, Pune, India \\ E-mail: shrawanowhal.mibm@gmail.com
}

Received: August 30, $2021 \quad$ Accepted: September 19, $2021 \quad$ Online Published: October 25, 2021

DOI: $10.46281 /$ ijfb.v8i1.1402

URL: https://doi.org/10.46281/ijfb.v8i1.1402

\begin{abstract}
Demonetization is the withdrawal of a particular form of currency from circulation. In other words, the notes lose their value as a currency. It is an instrument that is used to manage various economic problems such as inflation, corruption, tax evasion, etc. The Indian government on November 8, 2016, decided to demonetize high denomination currencies. This announcement had an impact on several sectors of the Indian economy. This study is an investigation to measure the impact of demonetization announcements on the Indian banking sector. This study employs cumulative abnormal return (CAR) and an event study methodology to measure the impact of the decision on the selected banking stocks. The study shows that demonetization had a significant impact on the stock prices of selected banks. The findings of the study suggest that on the event day, none of the selected stock has shown significant positive abnormal returns. Further on the event day and followed by the event day positive significant $A R R$ is observed indicating demonetization had a significant impact on the stock prices of selected banks. Also, CAR on the event day is not equal to zero indicating the Indian stock market was not efficient for demonetization announcement.
\end{abstract}

Keywords: Demonetization, Indian Banking Sector, Cumulative Abnormal Return, Event Study Methodology.

JEL Classification Codes: G10, G14, G18, G21.

\section{INTRODUCTION}

Demonetization is the withdrawal of a particular form of currency from circulation. Notes of a particular denomination cease to be legal tender. In other words, the notes lose their value as a currency. The 
demonetization is usually done to tackle black money, corruption, to curb fake currency and to curtail shadow economy. It is expected that demonetization will also bring down the use of illicit money for funding smuggling and terrorism. Countries across the globe have used demonetization at some or the other point to control inflation and to boost the economy. On 8th November 2016, the Government of India announced Demonetization of INR 500 and INR 1000 banknotes. It was announced in an unscheduled live telecast addressed by Prime Minister Mr. Narendra Modi. The demonetization may have a different effect on the various industries. This depends on the demand and supply of hard cash in the respective sector. Industries in the informal sector where hard cash play significant role had affected more than the formal sector. The impact of demonetization can be studied from the financial statements of companies from the various sector. Comparative analysis of sales, profit, etc. over a period of time will help to measure the impact. As demonetization affected various sectors this will be reflected in the share price of companies within those sectors.

Demonetization was an unexpected public announcement. Following the day of the announcement, i.e. on $9^{\text {th }}$ November 2016 , the NSE's Nifty dropped by 541.30 points i.e. $6.33 \%$ and BSE's Sensex by 1688 points i.e. $6.12 \%$. The Indian currency was down by 23 paise and was trading at INR 66.85 per US \$. This announcement can be considered under efficient market hypothesis, which states that the stock market is a good indicator of sentiments of investors and it discounts and reflects the information quickly. It is interesting to know the reaction of Indian Stock market to demonetization. The present study is an attempt to investigate the impact of demonetization on the share price of the selected public sector and private sector banks.

\section{LITERATURE REVIEW}

Bharadwaj, Mohith, Pavithra, and Anaath (2017) studied the impact of demonetization on Indian stock market by using efficient market hypothesis. The study is based on the 16 companies listed on NSE belonging to four different sectors viz. media, energy, private banking and realty. The observations are based on a period of five years from 2012 to 2016 before demonetization and 5 months November 2016 to March 2017 after demonetization. A Sharpe index model is used to construct an optimum portfolio. The risk and return values are calculated to evaluate the stock. The results reveal that there was a significant impact of demonetization on Indian stock market along with some fluctuations.

Chauhan and Kaushik (2017) studied the impact of demonetization on Indian stock market. The study observed the price movement of the stocks during the pre and post announcement of demonetization for the period of $30^{\text {th }}$ October 2016 to $21^{\text {st }}$ November 2016. The event study methodology used to analyze the impact of demonetization the share price of BSE 100 companies. The study used OLS Market Model, Market-Adjusted Return Model and Mean-Adjusted Return Model and checked the significance of AAR and CAAR for each model using t statistics. The result states that there is no significant impact of demonetization on the Indian stock market prices.

Tiwari and Anjum (2017) researched the opinion of management students, faculties and bankers to analyses the impact of demonetization. The study is based on the survey conducted using a questionnaire in Pune city of Maharashtra state. The results of the study reveal that the respondent considered no significant impact of demonetization on terrorism. It is observed that the respondents were moderately satisfied with the effect of demonetization on reducing fake currency. Respondents agreed that demonetization helped in increasing tax compliance. It is also observed that the respondent had a neutral opinion regarding the planning and execution of demonetization.

Kumar (2018) studied the impact of demonetization on sectoral indices in the Indian stock market after one year of announcement. The study used paired sample t-test to understand the impact of demonetization on the indices of various sectors. The study noted an increase in the index value of few sectors like metal, financial services and oil and gas while there was a decrease in the index value of sectors consisting of the automobile, FMCG and pharma.

Lodha, Kumawat, and Bapna (2018) studied whether or not Indian stock market overreacted to the demonetization news. The study is based on the event study methodology consisting of an event window of 21 days $(+10,0,-10)$ and an estimation window of 81 days. The study used a market model 
to check the significance of AAR using t statistics. The result of the study shows that demonetization has affected different indices differently. Financial services and banks yielded positive AR and CAR, while real estate, IT, Auto, and media produced negative ARs and CARs.

There are very few studies conducted on the demonetization. Furthermore from the literature, it is observed that most of the studies are related to the impact of demonetization on the stock market and sectoral indices. Few studies are based on understanding the opinions of various stakeholders of the economy on demonetization. In the literature, the impact of demonetization on the share price of banking companies remain relatively unexplored. This paper attempts to study the impact of demonetization on the share price of banking sector companies with the following objectives:

\section{OBJECTIVES}

- To study the effects of demonetization on return on selected stocks of banks.

- To compare changes in stock prices of selected public sector banks and private sector banks over an event window.

\section{HYPOTHESIS OF THE STUDY}

- $\mathrm{H}_{0}$ : Demonetization announcement has no significant impact on stock prices of selected banks.

- $\mathrm{H}_{1}$ : Demonetization announcement has a significant impact on stock prices of selected banks

\section{DATA SOURCE AND SAMPLING}

To evaluate the objectives of the study, secondary data were used (BSE Limited, 2021). Top 5 public sector banks (PSBs) and top 5 private sector banks (PVSBs) based on total assets (as on dated 9 September 2019) are considered for the study.

\section{METHOD}

- The event study methodology is used to measure the market reaction to demonetization news. Demonetization is announced on the evening of $8^{\text {th }}$ November 2016 (after trading hours), therefore $9^{\text {th }}$ November is considered as event day $\left(\mathrm{t}_{0}\right) .7$ trading days before and after demonetization and event day is considered as event window ( $30^{\text {th }}$ October to $21^{\text {st }}$ November 2016). 100 days ( $3^{\text {rd }}$ June to $28^{\text {th }}$ October 2016.) estimation window is considered (eventstudytools).

- Event study methods quantify the economic impact of an event on abnormal returns. Market model (Equation 1) is used to calculate the abnormal return.

$$
A R_{i, t}=R_{i, t}-\left(\alpha_{i}+\beta_{i} R_{\mathrm{m}, t}\right)
$$

$\mathrm{AR}_{\mathrm{i}, \mathrm{t}}=$ Abnormal Return,

$\mathrm{R}_{\mathrm{i}, \mathrm{t}}=$ Actual Return

$\mathrm{R}_{\mathrm{m}}=$ Market return (BSE 200 is considered as a market benchmark.)

$\alpha_{i}=$ The excess return of an investment relative to the return of a benchmark index

$\beta_{i}=$ A stock's volatility in relation to the market

Following equations are used to calculate average abnormal return and cumulative average abnormal return.

$$
\begin{aligned}
& A R R=\frac{1}{n} \sum_{i=1}^{N} A R_{i, t} \\
& C A R(t 1, t 2)=\sum_{t=t 1}^{t 2} A R_{i, t}
\end{aligned}
$$

- The excess return of an investment relative to the return of a benchmark index ( $\alpha)$, a stock's volatility in relation to the market $(\beta)$ and standard error are computed using the market return of estimation window. 
- $t$ statistics (Equation 4)is used to measure the impact of demonetization event on the share price. t statistics=AAR (for each day of event window)/ Standard error (of estimation window)

\section{Descriptive Statistics}

\section{DATA ANALYSIS}

Following table (Table1) shows values of stock's volatility in relation to the market $(\beta)$, the excess return of an investment relative to the return of a benchmark index $(\alpha)$ and standard error using regression.

Table 1. Statistical Measures

\begin{tabular}{|c|c|c|c|}
\hline Bank Name & Beta & Alpha & Standard Error \\
\hline SBI & 0.2273 & 0.0028 & 0.0177 \\
\hline PNB & 0.5587 & 0.0070 & 0.0272 \\
\hline BOB & 0.2814 & 0.0014 & 0.0225 \\
\hline CB & 0.3275 & 0.0050 & 0.0236 \\
\hline BOI & 0.5340 & 0.0035 & 0.0244 \\
\hline HDFC & 0.0885 & 0.0008 & 0.0089 \\
\hline ICICI & -0.2222 & 0.0014 & 0.0212 \\
\hline AXIS & -0.0743 & -0.0006 & 0.0187 \\
\hline YES & 0.1712 & 0.0022 & 0.0173 \\
\hline KOTAK & 0.1067 & 0.0010 & 0.0113 \\
\hline
\end{tabular}

Beta is used to measure the systematic risk of a stock in relation to market risk. Beta for each of the banking stock is calculated considering BSE 200 as a benchmark. All the banking stocks have positive beta except ICICI Bank and Axis bank. As the beta of all the selected banking stocks is less than 1, this indicates that stocks are less volatile than the benchmark. PNB has the highest beta of 0.5587, while HDFC has the lowest beta of 0.0885 . A negative beta of -0.0743 and -0.2222 is observed for Axis bank and ICICI bank respectively, indicating movement of stock in the opposite direction from the benchmark. From the beta values, it can be inferred that stocks of public sector banks are riskier than stocks of private sector banks.

The alpha value indicates the performance of a stock in comparison with the market. The positive value of alpha indicates that stock is outperforming the market. All the stocks have positive values except for Axis bank. The highest value of 0.007 is recorded for Punjab National Bank, while the lowest value of 0.001 is recorded for Kotak Mahindra bank. Overall stocks of public sector banks have a better value of alpha than stocks of private sector banks.

Standard error value represents the sample. A lower value of standard error indicates the accuracy of the sample. HDFC Bank has the lowest standard error of 0.0089 , while Punjab National Bank has the highest standard error of 0.072. From the values of standard error, it can be concluded that the sample is fair and it is representing the population accurately.

\section{Abnormal Return Analysis}

In this section abnormal return of each stock for each day during the event window is analyzed. Table 2 presents the Abnormal Return Analysis and t- statistics of Public sector Banks and Private Sector Banks for event window i.e. for a pre-event period (-7 to -1$)$ and post-event period (7 to 1). 
Table 2. Abnormal Return Analysis of Public sector Banks for the event window

\begin{tabular}{|c|c|c|c|c|c|c|c|c|c|c|}
\hline \multirow[t]{2}{*}{ Day } & \multicolumn{2}{|c|}{ SBI } & \multicolumn{2}{|c|}{ PNB } & \multicolumn{2}{|c|}{ BOB } & \multicolumn{2}{|c|}{ CB } & \multicolumn{2}{|c|}{ BOI } \\
\hline & $\mathbf{A R}$ & $\begin{array}{c}\mathbf{t}- \\
\text { statistic } \\
\mathrm{S}\end{array}$ & $\mathbf{A R}$ & $\begin{array}{c}\mathrm{t}- \\
\text { statistics }\end{array}$ & $\overline{A R}$ & $\begin{array}{c}\mathbf{t}- \\
\text { statistics }\end{array}$ & $\mathbf{A R}$ & $\begin{array}{c}\mathbf{t}- \\
\text { statistics }\end{array}$ & $\overline{A R}$ & $\begin{array}{c}\mathbf{t}- \\
\text { statistic } \\
\mathrm{S}\end{array}$ \\
\hline-7 & $-0.50 \%$ & -0.28 & $-0.94 \%$ & -0.35 & $-0.45 \%$ & -0.20 & $-0.72 \%$ & -0.31 & $-0.80 \%$ & -0.33 \\
\hline-6 & $-0.27 \%$ & -0.15 & $-1.87 \%$ & -0.69 & $-0.89 \%$ & -0.39 & $-1.71 \%$ & -0.73 & $-1.81 \%$ & -0.74 \\
\hline-5 & $-3.12 \%$ & -1.76 & $-5.64 \%$ & -2.07 & $-3.49 \%$ & -1.55 & $-6.27 \%$ & -2.66 & $-4.59 \%$ & -1.88 \\
\hline-4 & $-2.62 \%$ & -1.48 & $-3.57 \%$ & -1.31 & $-2.40 \%$ & -1.07 & $-0.08 \%$ & -0.03 & $-0.77 \%$ & -0.32 \\
\hline-3 & $-1.49 \%$ & -0.84 & $-2.05 \%$ & -0.75 & $-3.07 \%$ & -1.37 & $-2.60 \%$ & -1.10 & $-2.83 \%$ & -1.16 \\
\hline-2 & $3.97 \%$ & 2.24 & $6.37 \%$ & 2.34 & $4.03 \%$ & 1.79 & $2.90 \%$ & 1.23 & $2.10 \%$ & 0.86 \\
\hline-1 & $-0.07 \%$ & -0.04 & $0.19 \%$ & 0.07 & $0.80 \%$ & 0.36 & $-0.94 \%$ & -0.40 & $0.69 \%$ & 0.28 \\
\hline 0 & $2.50 \%$ & 1.41 & $0.47 \%$ & 0.17 & $1.25 \%$ & 0.56 & $0.63 \%$ & 0.27 & $0.33 \%$ & 0.13 \\
\hline 1 & $8.19 \%$ & 4.62 & $11.30 \%$ & 4.15 & $8.96 \%$ & 3.98 & $6.31 \%$ & 2.68 & $\begin{array}{c}12.74 \\
\%\end{array}$ & 5.22 \\
\hline 2 & $-3.38 \%$ & -1.91 & $-3.06 \%$ & -1.12 & $-2.63 \%$ & -1.17 & $-3.35 \%$ & -1.42 & $-2.08 \%$ & -0.85 \\
\hline 3 & $1.45 \%$ & 0.82 & $-1.86 \%$ & -0.68 & $8.17 \%$ & 3.63 & $0.59 \%$ & 0.25 & $0.18 \%$ & 0.08 \\
\hline 4 & $-0.82 \%$ & -0.46 & $-4.94 \%$ & -1.81 & $-0.99 \%$ & -0.44 & $0.36 \%$ & 0.15 & $-2.53 \%$ & -1.04 \\
\hline 5 & $-0.08 \%$ & -0.04 & $-1.42 \%$ & -0.52 & $0.73 \%$ & 0.33 & $0.75 \%$ & 0.32 & $-1.42 \%$ & -0.58 \\
\hline 6 & $-1.03 \%$ & -0.58 & $0.54 \%$ & 0.20 & $0.95 \%$ & 0.42 & $0.19 \%$ & 0.08 & $0.84 \%$ & 0.34 \\
\hline 7 & $-6.59 \%$ & -3.72 & $-9.01 \%$ & -3.31 & $-8.53 \%$ & -3.79 & $-6.12 \%$ & -2.60 & $-3.40 \%$ & -1.39 \\
\hline \multirow[t]{2}{*}{ Day } & \multicolumn{2}{|c|}{ HDFC } & \multicolumn{2}{|c|}{ ICICI } & \multicolumn{2}{|c|}{ AXIS } & \multicolumn{2}{|c|}{ YES } & \multicolumn{2}{|c|}{ KOTAK } \\
\hline & $\mathbf{A R}$ & $\begin{array}{c}t- \\
\text { statistic } \\
S \\
\end{array}$ & $\mathbf{A R}$ & $\begin{array}{c}\mathrm{t}- \\
\text { statistics }\end{array}$ & $\mathbf{A R}$ & $\begin{array}{c}\mathbf{t}- \\
\text { statistics }\end{array}$ & AR & $\begin{array}{c}\mathbf{t}- \\
\text { statistics }\end{array}$ & $\mathbf{A R}$ & $\begin{array}{c}t- \\
\text { statistic } \\
s \\
\end{array}$ \\
\hline-7 & $-0.60 \%$ & -0.67 & $-0.03 \%$ & -0.02 & $0.40 \%$ & 0.22 & $-0.70 \%$ & -0.41 & $0.32 \%$ & 0.28 \\
\hline-6 & $0.34 \%$ & 0.39 & $-0.61 \%$ & -0.28 & $-2.38 \%$ & -1.28 & $-1.78 \%$ & -1.03 & $-1.95 \%$ & -1.72 \\
\hline-5 & $-1.19 \%$ & -1.34 & $-1.37 \%$ & -0.65 & $0.16 \%$ & 0.08 & $-3.37 \%$ & -1.95 & $-0.43 \%$ & -0.38 \\
\hline-4 & $0.74 \%$ & 0.83 & $-0.86 \%$ & -0.40 & $0.07 \%$ & 0.04 & $-0.56 \%$ & -0.32 & $0.12 \%$ & 0.11 \\
\hline-3 & $-1.12 \%$ & -1.26 & $-0.15 \%$ & -0.07 & $0.63 \%$ & 0.34 & $-1.16 \%$ & -0.67 & $-0.87 \%$ & -0.77 \\
\hline-2 & $0.49 \%$ & 0.55 & $3.04 \%$ & 1.43 & $1.31 \%$ & 0.70 & $0.72 \%$ & 0.42 & $0.24 \%$ & 0.22 \\
\hline-1 & $0.39 \%$ & 0.43 & $1.23 \%$ & 0.58 & $1.29 \%$ & 0.69 & $1.45 \%$ & 0.84 & $1.18 \%$ & 1.04 \\
\hline 0 & $-0.31 \%$ & -0.34 & $-0.71 \%$ & -0.33 & $-0.53 \%$ & -0.28 & $-0.64 \%$ & -0.37 & $1.48 \%$ & 1.30 \\
\hline 1 & $1.89 \%$ & 2.11 & $3.69 \%$ & 1.74 & $3.90 \%$ & 2.09 & $5.69 \%$ & 3.28 & $-0.54 \%$ & -0.48 \\
\hline 2 & $-0.12 \%$ & -0.13 & $-5.48 \%$ & -2.58 & $-1.54 \%$ & -0.82 & $-6.04 \%$ & -3.49 & $-0.78 \%$ & -0.68 \\
\hline 3 & $-1.73 \%$ & -1.94 & $-2.82 \%$ & -1.33 & $-3.73 \%$ & -2.00 & $-4.99 \%$ & -2.88 & $\begin{array}{c}- \\
3.37 \%\end{array}$ & -2.97 \\
\hline 4 & $-1.04 \%$ & -1.17 & $-1.15 \%$ & -0.54 & $-1.33 \%$ & -0.71 & $1.43 \%$ & 0.82 & $\begin{array}{c}-\overline{6} \\
2.63 \%\end{array}$ & -2.32 \\
\hline 5 & $-1.21 \%$ & -1.35 & $0.36 \%$ & 0.17 & $0.56 \%$ & 0.30 & $-0.61 \%$ & -0.35 & $0.79 \%$ & 0.69 \\
\hline 6 & $-1.56 \%$ & -1.75 & $-1.31 \%$ & -0.61 & $-0.11 \%$ & -0.06 & $0.20 \%$ & 0.12 & $0.36 \%$ & 0.31 \\
\hline 7 & $-1.09 \%$ & -1.22 & $-1.46 \%$ & -0.69 & $-1.61 \%$ & -0.86 & $-5.78 \%$ & -3.34 & $-2.17 \%$ & -1.92 \\
\hline
\end{tabular}

All the public sector banks reacted positively to the announcement of demonetization. This can be observed in a positive return on the event date. In the private sector, all banks except Kotak Mahindra bank reacted negatively to the event. It is interesting to note that all banking stocks except Kotak 
Mahindra Bank show a positive return on the $(t+1)$ day. In the long run, most of the banks show a negative return. Also, none of the banks except SBI and PNB shows statistically significant positive abnormal return before the event. This approves that people were not aware of the news before its announcement and it was shocking news for everyone.

\section{Cumulative Abnormal Return Analysis}

This section analyses the cumulative abnormal returns of each security over a period of 15 days, i.e. within the event window to get an idea about the average behaviour of a particular stock. It can be observed from table 3 that pre-event window; CAR of all banks except ICICI Bank and Axis banks is negative. On demonetization day all PSBs has shown an increase in return for investors while all PVSBs except Kotak Mahindra bank shows a negative return. In the post-event window stocks of SBI and BOB earn positive returns while the stock of the rest of the banks earns negative returns.

Table 3. Cumulative Abnormal Return Analysis

\begin{tabular}{|c|c|c|c|c|c|}
\hline Day & SBI & PNB & BOB & CB & BOI \\
\hline-7 & $-0.50 \%$ & $-0.94 \%$ & $-0.45 \%$ & $-0.72 \%$ & $-0.80 \%$ \\
\hline-6 & $-0.78 \%$ & $-2.81 \%$ & $-1.34 \%$ & $-2.44 \%$ & $-2.61 \%$ \\
\hline-5 & $-3.89 \%$ & $-8.45 \%$ & $-4.83 \%$ & $-8.71 \%$ & $-7.20 \%$ \\
\hline-4 & $-6.51 \%$ & $-12.02 \%$ & $-7.23 \%$ & $-8.78 \%$ & $-7.97 \%$ \\
\hline-3 & $-8.00 \%$ & $-14.07 \%$ & $-10.30 \%$ & $-11.38 \%$ & $-10.80 \%$ \\
\hline-2 & $-4.03 \%$ & $-7.70 \%$ & $-6.28 \%$ & $-8.48 \%$ & $-8.70 \%$ \\
\hline-1 & $-4.10 \%$ & $-7.51 \%$ & $-5.48 \%$ & $-9.42 \%$ & $-8.01 \%$ \\
\hline 0 & $-1.60 \%$ & $-7.04 \%$ & $-4.23 \%$ & $-8.79 \%$ & $-7.68 \%$ \\
\hline 1 & $6.58 \%$ & $4.26 \%$ & $4.73 \%$ & $-2.48 \%$ & $5.06 \%$ \\
\hline 2 & $3.20 \%$ & $1.20 \%$ & $2.10 \%$ & $-5.83 \%$ & $2.98 \%$ \\
\hline 3 & $4.66 \%$ & $-0.66 \%$ & $10.27 \%$ & $-5.24 \%$ & $3.16 \%$ \\
\hline 4 & $3.84 \%$ & $-5.60 \%$ & $9.28 \%$ & $-4.88 \%$ & $0.63 \%$ \\
\hline 5 & $3.76 \%$ & $-7.02 \%$ & $10.01 \%$ & $-4.12 \%$ & $-0.79 \%$ \\
\hline 6 & $2.73 \%$ & $-6.48 \%$ & $10.96 \%$ & $-3.93 \%$ & $0.05 \%$ \\
\hline 7 & $-3.87 \%$ & $-15.48 \%$ & $2.43 \%$ & $-10.05 \%$ & $-3.35 \%$ \\
\hline Day & HDFC & ICICI & AXIS & YES & КОТАК \\
\hline-7 & $-0.60 \%$ & $-0.03 \%$ & $0.40 \%$ & $-0.70 \%$ & $0.32 \%$ \\
\hline-6 & $-0.26 \%$ & $-0.64 \%$ & $-1.98 \%$ & $-2.48 \%$ & $-1.63 \%$ \\
\hline-5 & $-1.45 \%$ & $-2.01 \%$ & $-1.82 \%$ & $-5.85 \%$ & $-2.05 \%$ \\
\hline-4 & $-0.70 \%$ & $-2.87 \%$ & $-1.75 \%$ & $-6.41 \%$ & $-1.93 \%$ \\
\hline-3 & $-1.83 \%$ & $-3.02 \%$ & $-1.11 \%$ & $-7.57 \%$ & $-2.80 \%$ \\
\hline-2 & $-1.33 \%$ & $0.01 \%$ & $0.20 \%$ & $-6.85 \%$ & $-2.56 \%$ \\
\hline-1 & $-0.95 \%$ & $1.25 \%$ & $1.49 \%$ & $-5.40 \%$ & $-1.38 \%$ \\
\hline 0 & $-1.25 \%$ & $0.54 \%$ & $0.96 \%$ & $-6.03 \%$ & $0.09 \%$ \\
\hline 1 & $0.63 \%$ & $4.23 \%$ & $4.86 \%$ & $-0.34 \%$ & $-0.45 \%$ \\
\hline 2 & $0.52 \%$ & $-1.25 \%$ & $3.33 \%$ & $-6.39 \%$ & $-1.22 \%$ \\
\hline 3 & $-1.21 \%$ & $-4.06 \%$ & $-0.40 \%$ & $-11.38 \%$ & $-4.59 \%$ \\
\hline 4 & $-2.26 \%$ & $-5.21 \%$ & $-1.73 \%$ & $-9.95 \%$ & $-7.22 \%$ \\
\hline 5 & $-3.46 \%$ & $-4.86 \%$ & $-1.18 \%$ & $-10.56 \%$ & $-6.43 \%$ \\
\hline 6 & $-5.03 \%$ & $-6.16 \%$ & $-1.29 \%$ & $-10.35 \%$ & $-6.08 \%$ \\
\hline 7 & $-6.11 \%$ & $-7.62 \%$ & $-2.90 \%$ & $-16.13 \%$ & $-8.25 \%$ \\
\hline
\end{tabular}




\section{Average Abnormal Return and Cumulative Average Abnormal Return Analysis}

To measure the impact of the event on the selected stock ARR and t statistics of day-wise ARR is calculated. From Table 4 it can be observed that the pre-announcement period there are two incidences of positive ARR on t-1 and t-2 day. After the announcement, there is one incidence of positive ARR on $\mathrm{t}+1$ day followed by negative ARR indicating low confidence of investors in the banking stocks. Also on vent day, there is a positive ARR of $0.004 \%$ which is significant at $5 \%$. From this null hypothesis is rejected and an alternate hypothesis is accepted. Demonetization announcement has a significant impact on the stock prices of selected banks.

Table 4. Average ARR and t statistics

\begin{tabular}{|c|c|c|}
\hline Day & AAR & t stat \\
\hline-7 & -0.004 & $-6.01^{*}$ \\
\hline-6 & -0.013 & $-19.28^{*}$ \\
\hline-5 & -0.029 & $-43.74^{*}$ \\
\hline-4 & -0.010 & $-14.79^{*}$ \\
\hline-3 & -0.015 & $-21.97^{*}$ \\
\hline-2 & 0.025 & $37.57^{*}$ \\
\hline-1 & 0.006 & $9.26^{*}$ \\
\hline 0 & 0.004 & $6.67^{*}$ \\
\hline 1 & 0.062 & $92.73^{*}$ \\
\hline 2 & -0.028 & $-42.46^{*}$ \\
\hline 3 & -0.008 & $-12.08^{*}$ \\
\hline 4 & -0.014 & $-20.38^{*}$ \\
\hline 5 & -0.002 & $-2.29^{*}$ \\
\hline 6 & -0.001 & -1.37 \\
\hline 7 & -0.046 & $-68.3^{*}$ \\
\hline \multicolumn{3}{|c|}{$*$-t stats is significant at 5\% } \\
\hline
\end{tabular}

\section{CONCLUSION}

This study is based on the impact of demonetization announcement on the selected stocks of the banking sector in India. This research is based on the standard event study methodology. The study observed that there is no significant difference in the abnormal returns before demonetization announcement indicating that there was no seepage of information, and therefore we can say that this only handful of people were aware of this event. On the event day, none of the selected stock has shown significant positive abnormal returns. Further on the event day and followed by the event day positive significant ARR is observed indicating demonetization had a significant impact on the stock prices of selected banks. Also, CAR on the event day is not equal to zero indicating the Indian stock market was not efficient for demonetization announcement.

\section{REFERENCES}

Bharadwaj, R., Mohith, S., Pavithra, S., \& Anaath, A. (2017). Impact of demonetization on Indian stock market. International Journal of Management, 8(3), 75-82.

BSE Limited. (2021). Retrieved from https://www.bseindia.com

Chauhan, S., \& Kaushik, N. (2017). Impact of Demonetization on Stock Market: Event Study Methodology. Indian Journal of Accounting, 127-132. 
eventstudytools. (n.d.). eventstudytools. Retrieved from https://www.eventstudytools.com

Kumar, A. (2018). Demonetization Effect on Sectorial Indices with Special Reference to Indian Stock Market- An Empirical Analysis. International Research Journal of Management and Commerce, 5(4), 358-373.

Lodha, S., Kumawat, E., \& Bapna, C. (2018). Impact of Demonetization Announcement on Indian Stock Market: An Event Study. Nirnay The Journal of Decision Science, 4-16.

Tiwari, R., \& Anjum, B. (2017). Review of Demonetization in India. SaiBalaji International Journal of Management Sciences, 1 .

\section{Copyrights}

Copyright for this article is retained by the author(s), with first publication rights granted to the journal. This is an open-access article distributed under the terms and conditions of the Creative Commons Attribution license (https://creativecommons.org/licenses/by/4.0) 